Изучение русской литературы в Чехии и Словакии (2006-2015 гг.) ${ }^{1}$ : Аннотированная библиография

A.V. Zlochevskaya (Moscow, Russia)

\title{
Study of Russian Literature in Czech Republic and Slovakia: Annotated Bibliography
}

\section{УЧЕБНИКИИ УЧЕБНЫЕПОСОБИЯ, ХРЕСТОМАТИИ, СЛОВАРИ}

Antoňák A. Ruská literatura 20. storočia I. Prešov: Prešovská univerzita, 2007. $165 \mathrm{~s}$. Учебное пособие на русском языке. Русская литература первой половины XX в.: литературный процесс и «медальоны» поэзии Серебряного века, творчество И. Бунина, Л. Андреева, М. Горького, А. Блока, С. Есенина и др. Словарь литературоведческих терминов и понятий художественной литературы того времени.

Dohnal J. Русская литература XVIII века.. Избранные тексты. Хрестоматия. Brno: Masarykova univerzita. T. I. 2013. 266 s.; T. II. 2014. 278 s.

Историко-биографические очерки о видных деятелях русской культуры и тексты их сочинений: Петр I, Феофан Прокопович, А.Д. Кантемир, В.К. Тредиаковский, А.П. Сумароков, М.В. Ломоносов, Д.И. Фонвизин, Н.И. Новиков, И.А. Крылов, Г.Р. Державин, Н.М. Карамзин, А.Н. Радищев и др.

Eliáš a kol. Ruská literatúra 18. - 21. storočia. Bratislava: Veda, 2013. 240 s.

Учебник. История русской изящной словесности XVIII-XI вв. в социокультурном аспекте в широком контексте словацких, чешских и общеевропейских культурных процессов. Представлен художественный процесс исследуемого периода как единое целое: весь спектр направлений, течений, школ и объединений, в том числе литература андеграунда и эмиграции, жанровая палитра словесности на всех этапах ее развития.

Jehlička M. Aby se literatura stala inspirací: ruská literatura očima Miloslava Jehličky / [k nedožitým pětaosmdesátinám Miloslava Jehličky uspořádal, upravil a autorovu bibliografii zkompletoval Stanislav Rubáš]. Praha: Karolinum, 2006. 85 s.

Учебник. Текст неоконченного труда. Русская литература XVIII - первой трети XIX в.: художественный процесс и «медальоны».

Kupko V., Kupková I. Krátky slovník ruskej kultúry 20. storočia. Prešov: Prešovská univerzita, 2009. $150 \mathrm{~s}$.

Словарь. Русская культура XX в.

Kupko V., Kupková I,, Harbul'ová L. Slovník ruskej umeleckej kultúry 20. storočia. Prešov: Prešovská univerzita, 2014. $296 \mathrm{~s}$.

\footnotetext{
${ }^{1}$ В библиографию добавлены работы до 2006 г., не вошедшие в опубликованную ранее библиографию 1990-2005 гг. См.: Злочевская A.B. Изучение русской литературы в Чехии и Словакии в 1990-2005 гг.: Аннотированная библиография // Stephanos. 2014. № 7. С. 135-150.
} 
Словарь. Русская культура XX в.: литература, театр, музыка, изобразительное искусство, кино. Основные тенденции и пероналии, искания и эксперименты.

Kovačičová O. a kol. Slovník ruskej literatúry 11.-20. storočia. Bratislava: Veda, 2007. 581 s. Словарь. Русская литература XI-XX вв. в персоналиях (550 медальонов).

Patapava V., Pospíšil I. Slovník autorů literatury pro děti a mládež. 1-3. Zahraniční spisovatelé. Praha: LIBRI, 2007. T. 1: Běloruská literatura pro děti a mládež; T. 2: Ruská literatura pro děti a mládež; T. 3: Ukrainská literatura pro děti a mládež.

Словарь-справочник. Зарубежные (белорусские, русские и украинские) писатели - авторы литературы для детей и юношества.

Pospíšil I. Literární genologie. Brno: Masarykova univerzita, 2014. $118 \mathrm{s.}$

Учебное пособие. Общие проблемы генологии: концепции, основные понятия, литературные жанры, современное состояние дисциплины и др. Исследование проведено в том числе на материале русской литературы.

Pospísil I. Kapitoly z ruské klasické literatury: nástin vývoje, klíčové problémy a diskuse. Brno: Masarykova univerzita, 2014. 176 s.

Учебное пособие. Русская классическая литература: очерк развития изящной словесности XIX в., ключевые проблемы и дискуссии.

Pospišil I. Stará literatura východních Slovanů a ruská literatura 18. století: přehled a exkurzy s ukázkami textů z literatury 11.-17. století. Brno: Masarykova univerzita, 2014. $195 \mathrm{~s}$.

Учебное пособие. Русская литература XI-XVII вв. в контексте восточнославянского литературного процесса: очерк истории, сопоставительный анализ древнерусской и восточнославянской средневековой литератур, возникновение и формирование белорусской и украинской литератур и др.

Zahrádka M. a kol. Slovník rusko-českých literárných vztahů. Ústí nad Orlicí: Oftis, 2008. 320 s. Словарь-справочник. Русско-чешские литературные связи начиная с XVIII в. (около 300 статей): краткая характеристика творчества писателя, даты жизни; рецепция в Чехии: журнальные и книжные переводы, театральные инсценировки и экранизации, телевизионные постановки и радиопередачи, литературно-критические статьи и монографии о творчестве автора.

\section{РАБОТЫ СРАВНИТЕЛЬНО-ИСТОРИЧЕСКОГО ХАРАКТЕРА}

Červeňák A. Romantika hl'adania. Nitra: Univerzita Konštantína Filozófa, 2006. 145 s.

Монография. Русский романтизм в общеевропейском контексте. Аксиологический аспект.

Červeňák A. Tridsat' statí o slovenskej literatúre. Nitra: Univerzita Konštantína Filozófa, 2006. $138 \mathrm{~s}$. Авторский сборник. Словацко-русские литературные связи (влияние Достоевского на творчество В. Минача, М. Угрина, Я. Тужинского и др.).

Červeňák A. Štyridsat' statí o slovenskej literatúre. Nitra: Univerzita Konštantína Filozófa, 2010.95 s.

Авторский сборник. Словацко-русские литературные связи (Я. Штевчек и русская «формальная школа», М. Руфус - С. Есенин и др.).

Daniš M., Matula $V$. M.F. Rajevskij a Slováci v 19. storočí. Bratislava: Univerzita Komenského; STIMUL, 2014. 303 s.

Коллективная монография. Раевский М.Ф. - священник церквей при русских посольствах, общественный деятель славянофильского направления, писатель: жизнь и деятельность в Словакии XIX в.

Genologické a medziliterárne štúdie 1, 2. Prešov: Prešovská univerzita, 2009. T. 1. 164 s.; T. 2. $481 \mathrm{~s}$.

Сборник работ словацких и чешских ученых. Межлитературные связи и генология. В том числе на материале русской литературы (романы Ф.М. Достоевского).

Housková A., Svatoň $V$. Konec a počatek: literatury na přelomu dvou staletí. Praha: Univerzita Karlova, 2013. 212 s.

Коллективная монография. Модернизм в мировой литературе (на материале французской, испанской, скандинавских, русской и др. европейских литератур, а также испаноязычной Америки и Китая). 
Kšicová $D$. Od moderny k avantgardě. Rusko-české paralely. Brno: Masarykova univerzita, 2007. $516 \mathrm{~s}$.

Монография. Русское искусство конца XIX - первых десятилетий XX в. (изящная словесность, живопись, музыка, ваяние, архитектура, театр) в контексте мирового художественного процесса. Движение от модернизма к авангарду. Чешско-русские параллели.

Kšicová D. Cesty do Svaté Země XII.-XX. století. Mýty a realita v ruských a českých cestopisech. Brno: Masarykova univerzita, 2013. $336 \mathrm{~s}$.

Монография. Жанр «паломничества» на материале шести русских (игумена Даниила, И. Лукьянова, А. Белого и др.) и шести чешских (М. Кабатника, О. Префата, Я. Неруды и др.) текстов: жанровые границы, эволюция, тематика, стиль, мифопоэтическая картина мира, межлитературные параллели.

Mattová I., Lorková Z., Haburová A. Podoby a premeny reflexie ruskej literanury na Slovensku v rokoch 1996-2009. Bratislava: STIMUL, 2010. 105 s.

Коллективная монография. Русская литература - проза, поэзия, драматургия - в Словакии 19962009 гг:: изменения характера восприятия и вектора интересов; переводы произведений Г. Айги, В. Сорокина и др.

Mikulášek M. Via cordis: ars interpretationis hermeneuticae. Duchovědné paradigma literární hermeneutiky. Ostrava: Ostravská univerzita, 2011. 198 s.

Монография. «Искусство интерпретации» художественного текста: герменевтика против деконструктивизма и поструктурализма. Духовноведческий аспект искусства интерпретации. Размышления на материале европейской, в том числе русской (В. Набоков, М. Булгаков и др.), литературы.

Philologica LXIV. Zborník filozofické fakulty Univerzity Komenského. Ruská literatúra v súčasnej literárnovednej reflexii. Bratislava: Univerzita Komenského, 2008. 265 s.

Сборник работ русистов из Словакии, Чехии, России, Польши. Проблемы современной рецепции русской литературы XII-XX вв.: переводы, читательское восприятие, научное осмысление.

Pilátová $J$. Krátká zpráva v současné ruské a české publicistice: jazyk a text. Olomouc: Univerzita Palackého, 2009. $163 \mathrm{~s}$.

Монография. Жанр заметки в современной русской и чешской публицистике. Язык и текст. На материале текстов из центральных изданий («Известия», «Независимая газета», «Lidové noviny», «MF Dnes»), местных («Санкт-Петербургские ведомости», «Olomoucký Den»), бульварных («Экспресс газета», «Moravskoslezský Blesk») и оппозиционных («Правда»).

Pokorný M. Románová epopej v žánrových a meziliterárních souvislostech. Praha: Academia, 2007. $167 \mathrm{~s}$.

Монография. Теоретическое исследование жанровой модели романа-эпопеи в контексте межлитературных связей и параллелей. На материале произведений чешских, словацких и русских («Война и мир» Л.Н. Толстого и «Тихий Дон» М. Шолохова) писателей.

Pospišil I. Srovnávací studie (Komparatistika, slavistika, rusistika a česko-slovenské souvislosti). Trnava: Univerzita sv. Cyrila a Metoda, 2008. 262 s.

Монография. Сравнительные исследования: компаративистика, славистика, русистика, чешско-словацкие отношения.

Pospišil I. Základní okruhy filologické a literárněvědné metodologie a teorie (elementy, materiály, úvahy, pojetí, texty). Trnava: Univerzita sv. Cyrila a Metoda, 2010. 275 s.

Монография. Основные области теории и методологии филологических и литературоведческих наук (дисциплины, понятия, материалы, размышления, тексты). Обзор и критика филологических школ, в том числе русских («формальная школа» и др.). Чешско-русские параллели.

Pospišil I., Šaur J. Střední Evropa jako kulturní průsečík a Slované: tradice - perspektivy úskalí. Několik vybraných okruh. Brno: Masaryková univerzita, 2011. 114 s.

Коллективная монография. Компаративистика. Средняя Европа как перекресток культур и Славяне: традиции - перспективы - проблемы. В том числе взаимодействие культур Европы и России.

Pospišil I. Literatura v souvislostech. Několik příběhů o tom, jak také číst literaturu z širšího pohledu. České Budějovice: Nakladatelství Vlastimil Johanus, 2011. $151 \mathrm{~s}$. 
Монография. Литература в контексте: восприятие художественного произведения на фоне мировой литературы, как современной инонациональной, так и изящной словесности прошлого. В том числе на материале русской изящной словесности.

Pospišil I. K teorii ruské literatury a jejím souvislostem. Brno: Masarykova univerzita, 2013. $271 \mathrm{~s}$. Монография. Русская литература XI-XX вв. в контексте общеевропейского литературного процесса; взгляд извне и изнутри. Своеобразие русской литературы, жанровая структура и формы, роман. Современная теория ареальных, межлитературных и межкультурных связей. Чешско-русские связи.

Pospísil I., Zelenka M. a kol. Kontexty literární vědy V. Brno: Tribun Evropské Unie, 2014. 179 s. Сборник работ славистов из Чехии, Словакии. Современное восприятие и переосмысление творчества писателей, поэтов и литературоведов прошлого, в том числе русских (А.С. Пушкин, С. Залыгин, поэты «Лианозовской группы»). Проблемы перевода.

Pospiśsil I. Методология и теория литературоведческой славистики и Центральная Европа. Siedlice: Uniwersyteta Przyrodniczo-Humanistycznego, 2015. 184 s.

Монография. Современное состояние «ареальных» исследований. Среднеевропейская литературная общность. Роль русской литературы.

Žemberová $V$. Z morfológie prózy. Prešov: Prešovská unuverzita, 2012. $253 \mathrm{~s}$.

Авторский сборник. Проблемы прозы: морфология, жанр и поэтика на материале словацкой и чешской, а также русской (Н.В. Гоголь, Ф.М. Достоевский, А.П. Чехов, М. Агеев) литератур.

\section{ИССЛЕДОВАНИЯ, ОХВАТЫВАЮЩИЕ НЕСКОЛЬКО ПЕРИОДОВ РАЗВИТИЯ РУССКОЙ ЛИТЕРАТУРЫ}

Adamka P. Ruská publicistika (história, štýl). Nitra: Univerzita Konstantina Filozofa, 2010. $126 \mathrm{~s}$. Монография. Русская публицистика от XVIII в. до наших дней: история, характеристика основных изданий, эволюция стиля и др. Проблемы теории публицистического стиля: язык, место среди других функциональных стилей и др. Публицистический стиль в русской и словацкой филологической традиции.

Bínová $G$. Русская литературная эротика (Исторические и эстетические метаморфозы). Brno: Masarykova univerzita, 2006. 176 s.

Монография. Русский эротизм: история, философия, эстетика. На материале работ Вл. Соловьева, В.В. Розанова, Л. Карсавина, Н. Бердяева, П. Флоренского, С. Булгакова и др., а также произведений Ф.М. Достоевского, Л.Н. Толстого, Д. Мережковского, В. Набокова, Б. Пастернака, А. Платонова, В. Сорокина, Л. Улицкой и др.

Červeñák A. Reminiscencie esteticko-antropologické. Nitra: Univerzita Konštantína Filozófa, Spolok slovenských spisovatel'ov, Klub Fjodora Michajloviča Dostojevského, 2009. 166 s.

Авторский сборник. Эссе, размышления, исследования. Эстетико-антропологический аспект изучения изящной словесности, преимущественно русской: современная русистика, в том числе словацкая; русско-словацкие связи; проблемы перевода; Ф.М. Достоевский, М.М. Бахтин, русский модернизм и др.

Червеняк A. Русская литература в словацком восприятии. Nitra: Univerzita Konštantína Filozófa, 2007. $150 \mathrm{~s}$.

Авторский сборник. Русская литература XIX-XX вв. Рецепция в Словакии.

Червеняк $A$. Русская литература в восприятии проф. Андрея Червеняка. Нитра: Университет им. Константина философа, 2011. $221 \mathrm{s.}$

Авторский сборник. Статьи, эссе, размышления о русской литературе XIX-XX вв. Современная словацкая русистика: традиции и новые тенденции в рецепции.

Dekanová E., Semionovna N.V., Sokolová J. Kul'turnyje realii Rossiji. Nitra: Univerzita Konštantína Filozofa, 2010. 292 s.

Коллективная монография. Культурные реалии современной России: общественная жизнь, искусство, народный характер с точки зрения русского человека.

Eliáš A. Demiurg či reptajúca trstina? Lyrický subjekt v ruskej romantickej, postromantickej a neoromantickej poézii. Bratislava: Univerzita Komenského, 2008. $136 \mathrm{~s}$. 
Монография. Лирический субъект в русской поэзии романтизма и неоромантизма. На материале лирики В.А. Жуковского, К.Ф. Рылеева, А.С. Пушкина, М.Ю. Лермонтова, Ф.И. Тютчева, К. Бальмонта.

Hrala M. Ruská moderní literatura 1890-2000. Praha: Karolinum, 2007. 767 s.

Монография. История современной русской литературы (1890-2000) - дореволюционной, советской и зарубежной. Периодизация, направления, школы и группы, «медальоны» творчества отдельных авторов.

Hl'adanie ekvivalentnosti II. В поисках эквивалентности, Prešov: Prešovská univerzita, 2004. $607 \mathrm{~s}$.

Сборник работ русистов из Чехии, Словакии, России, Венгрии по материалам прошедшей в 2004 г в Прещове (Словакия) международной конференции. Русская литература XIX-XX вв.: реальность и художественная правда: критика церкви и тема детства в литературе XIX в., провокации М. Арцыбашева, Ф. Сологуба и А. Белого, символика в современной русской публицистике и др. Проблемы перевода.

Litteraria humanitas XIV. Problémy poetiky. Brno: Masarykova univerzita, Ústav slavistiky Filozofické fakulty, 2006. $388 \mathrm{~s}$.

Сборник работ славистов из Чехии, Словакии, России, Украины, Венгрии, Болгарии, Швеции, Германии, Австрии, Японии и др. Проблемы поэтики и компаративистики, в том числе на материале русской литературы (А.С. Пушкин, Ф.М. Достоевский, А. Белый, Н. Гумилев, А. Блок, В. Хлебников, А. Вознесенский, В. Пелевин и др.).

Litteraria humanitas XVI. Dialogy o slovanských literaturách: tradice a perspektivy. Brno: Masarykova univerzita, 2012. $244 \mathrm{~s}$.

Сборник работ славистов из Чехии, Словакии, России, Сербии, Италии, Польши, Германии и др. Славянские литературы: проблематика, топосы, поэтика, рецепция (в том числе на материале русской поэзии и прозы: А.С. Пушкин, И.С. Тургенев, М. Кузмин, Б. Пастернак, В. Шукшин и др.).

Olomoucké Dny Rusistů. XIX. Sborník př́spěvků z mezinárodní konference. 30.08-01.09.2007. Olomouc: Univerzita Palackého, 2008. 580 s.

Сборник работ русистов из Чехии, России, Польши, Бельгии, Германии и др. Русская литература от истоков до XX в.: поэзия, проза, драма; жанры, поэтика, литературные связи и др.

Olomoucké Dny Rusistů. XX. Sborník př́spěvků z mezinárodní konference. 02.09-04.09.2009. Olomouc: Univerzita Palackého, 2009. 450 s.

Сборник работ русистов из Чехии, России, Польши, Бельгии и др. Русская литература от истоков до XX в.: проблематика, топосы, поэтика и др.

Olomoucké Dny Rusistů. XXI. Sborník př́́spěvků z mezinárodní konference. 07.09-09.09.2011. Olomouc: Univerzita Palackého, 2011. 604 s.

Сборник работ русистов из Чехии, России, Польши и др. Русская литература XIX-XX вв.: диалог классики и современности (Ф.М. Достоевский, Л.Н. Толстой, Н.С. Лесков, И. Бунин, Л. Улицкая и др.).

Pašteková S. Proces, kánon, recepcia (historiografické, transl'atologické a interpretačné aspekty skumania ruskej literatóry). Bratislava: Veda, 2013. $140 \mathrm{~s}$.

Монография. Проблемы изучения русской литературы: историография, перевод и интерпретация. На материале произведений Н.В. Гоголя, Л.Н. Толстого, И. Бунина, А. Ахматовой, В. Ланина, В. Сорокина, Т. Толстой и др.

Pechal Z. Fenomén živlu v ruské literatuře. Olomouc: Univerzita Palackého. 264 s.

Монография. Русская литература XIX-XX вв. с точки зрения роли и функций в нем энтропии - как в процессе креации, так и во «внутреннем мире» произведения. На материале прозы А.С. Пушкина, Н.В. Гоголя, Ф.М. Достоевского, А. Белого, В. Набокова, Б. Пастернака и др.

Pospišil I. Pátrání po nové identitě. Rusistické a vztahové reflexe. Brno: Středoevropské centrum slovanských studií, 2008. 273 s.

Авторский сборник. Статьи, заметки, рецензии. В поисках новой идентичности: развитие русской словесности от общих восточнославянских истоков до конца ХХ в.

Tragédia doby, literatúry, človeka. Nitra: Univerzita Konštantína Filozofa, 2011. 341 s. Сборник работ русистов Словакии, России, Армении и Казахстана. Творчество Ф.М. Достоевского и М. Булгакова как отражение эпохи. Традиции и актуализация. 
Vobořil L. Ruská anekdota: žánr, jazyk, text. Olomouc: Univerzita Palackého, 2009. 111 s. Монография. Русский анекдот: жанр, язык, текст. Феномен русского анекдота как фольклорно-литературного жанра, акта коммуникации и др. Эволюция жанра.

\section{ДРЕВНЕРУССКАЯ ЛИТЕРАТУРА И РУССКАЯ ЛИТЕРАТУРА ХVІІ В.}

Komendová J. Světec a šaman. Kulturní kontexty ruské stredověke legendy. Praha Argo, 2011. 208 s. Монография «Святой и волхв». «Слово о житии святого Стефана, бывшего епископом Перми» (рубеж XIV-XV вв.) Епифания Премудрого: новаторство и консерватизм агиографического жанра; сюжет о миссионерской деятельности в рамках жанровой модели жития.

\section{РУССКАЯ ЛИТЕРАТУРА ХІХ в.}

Acta rossica Tyrnaviensis: zborník štúdií Katedry rusistiky Filozofickej fakulty Univerzity sv. Cyrila a Metoda. Brno: Tribun Evropské Unie, 2014. 175 s.

Сборник статей словацких русистов - лингвистика и литературоведение. В том числе на материале художественных текстов Н.В. Гоголя, Ф.И. Тютчева и др.

Pospišil I. На форпостах теории и истории классической русской литературы. Siedlce: Uniwersyteta Przyrodniczo-Humanistycznego, 2015. 202 s.

Монография. Проблемы поэтики русской классической литературы.

Repoň A. Umelecké zobrazenie človeka v románovom svete I.S. Turgeneva. Banská Bystrica: Univerzita Mateja Bela, 2011. $152 \mathrm{~s}$.

Монография. Человек как центр художественного мира И.С. Тургенева. Классификация образов героев. Персонаж как единство физического - душевного - духовного. Тургенев в восприятии русских символистов.

\section{н.в. ГОГОЛь}

Isačenko A.V. Nikolaj Vasilievič Gogol' i problemy russkogo realizma. Bratislava: Univerzita Komenského, 2003. 207 s.

Авторский сборник. Н.В. Гоголь и проблемы русского реализма.

Litteraria Humanitas XV. N.V. Gogol: Bytí díla v prostoru a čase (studie o čivém dědictví). Brno: Masarykova univerzita, Ústav slavistiky Filozofické fakulty: Tribun, 2010. $482 \mathrm{~s}$.

Сборник работ чешских, словацких и российских авторов. Различные аспекты современного восприятия гоголевского наследия: интерпретации, реминисценции и аллюзии в литературе постмодернизма, перевод.

Olomoucké Dny Rusistů. XXII. Sborník př́íspěvků z mezinárodní konference. 04.09-06.09.2013. Olomouc: Univerzita Palackého, 2014. 430 s.

Сборник работ русистов из Чехии, Словакии, России, Италии, Франции и др. Творчество Н.В. Гоголя: топосы, генология, поэтика, отзвуки в произведениях Н.С. Лескова, В. Маяковского, М. Цветаевой и др.

Пехал Зд., Зарянов О. и колл. Н.В. Гоголь как художественный и культурно-исторический феномен. Olomouc: Unverzita Palackého, 2015. 202 s.

Сборник работ русистов из Чехии, России, Украины и Германии. Творчество Н.В. Гоголя: особенности креативного процесса, литературные связи, поэтика, рецепция.

\section{Ф.М. ДОС Т ОЕ ВСК ИЙ}

Antoš M. Dostojevskij na Slovensku (F.M. Dostojevskij v zrkadle slovenskej publicistiky). Nitra: Garmond, Nitrianska obdočka Spolku slovenských spisovatel'ov, Klub F.M. Dostojevského, 2009. $136 \mathrm{~s}$.

Монография. Ф.М. Достоевский в «зеркале» словацкой публицистики.

Dostojevskij dnes: sborník př́spěvků z konference s mezinárodní účastí: (Praha, 27. listopadu 2006, Národní knihovna České republiky). Praha: Národní knihovna České republike, Slovanská knihovna, 2007. $183 \mathrm{~s}$. 
Сборник материалов конференции с участием ученых из Чехии, Словакии, России. Достоевский сегодня: восприятие, инонациональная рецепция и интерпретация произведений писателя в наши дни.

Dostojevskij a dnešok. Nitra: Univerzita Konštantína Filozofa, 2007. 330 s.

Сборник статей ученых из Чехии, Словакии, России. Современное восприятие и интерпретация наследия Достоевского.

Koukolik F. Proč se Dostojevskij mýlil? O vědomí, empatii, altruismu, lásce, zlu a religiozitě. Praha: Galén, 2007. 216 s.

Монография. Прав ли был Ф.М. Достоевский, утверждая: если Бога нет, то все позволено? Полемические размышления.

Pechal Z. a kol. Двойственность у Достоевского. Olomouc: Unverzita Palackého, 2011. 100 s. Сборник работ русистов из Чехии и России. Творчество Ф.М. Достоевского: особенности психологизма, жанровое своеобразие, поэтика.

Pytlik R. F.M. Djstojevskij. Život a dílo. Praha: Emporius, 2008. 207 s.

Монография. Жизнь и творчество Ф.М. Достоевского. «Проклятые вопросы», заданные писателем человечеству, в восприятии чешского читателя.

Sýkora M. Dostojevského buldok. O zviřatech a/v literature. Brno: Host, 2006. 196 s. Монография. Животные в творчестве Ф.М. Достоевского.

Tužinský J., Murin Š. Inkvizítor (dnes). Bratislava: CCW, 2006. 345 s.

Коллективная монография. «Великий Инквизитор» в современном восприятии.

\section{РУССКАЯ ЛИТЕРАТУРА ХХ в.}

Bulgakov a dnešok. Nitra: Univerzita Konštantína Filozofa, 2006. 252 s.

Сборник материалов научного семинара, прошедшего 23.11.2005 в Нитре. Творчество М. Булгакова: интерпретация произведений и современное восприятие; рецепция в Словакии.

Červeňák A. Na margo ruskej moderny. Nitra: Univerzita Konštantína Filozofa, 2012. $151 \mathrm{~s}$. Авторский сборник. Русский модернизм как литературное движение рубежа XIX-XX вв., охватывающее все сферы культурной жизни России: искусство, филологию, философию, науку и др.

Dohnal J. Proměny modelu světa v ruské próze na přelomu XIX. a XX. století. Brno: Masarykova univerzita, 2012. $178 \mathrm{~s}$.

Монография. Изменение модели мира в русской прозе рубежа XIX-XX вв. Художественная модель мира как таковая: аксиология, язык и символика. Феномен русской литературы в контексте европейского художественного процесса. На материале творчества Л.Н. Толстого, Л. Андреева, В. Брюсова, И. Шмелева.

Gazda J., Pospišil I. Proměny jazyka a literatury v současných ruských textech. Brno: Masarykova univerzita, 2007. $146 \mathrm{~s}$.

Коллективная монография. Русская литература конца XX в. с точки зрения методологии междисциплинарных социокультурных исследований и интеграционной типологии жанра. Метаморфозы языка художественных и публицистических текстов под влиянием кардинальных перемен в русском обществе 1980-1990-х гг.

Engelová $O$. Od moderny k avangarde. Nitra: Univerzita Konštantína Filozófa, 2006. 134 s. Монография. Русская поэзия XX в.: движение от модернизма к авангарду.

Engelová $O$. Študie a etúdy z ruskej poézie 20. storočia. Nitra: Univerzita Konštantína Filozófa, 2006. $140 \mathrm{~s}$.

Авторский сборник. Эссе и исследования о русской поэзии XX в.

Koryčánková S. Лексико-семантическое оформление философски значимых образов в поэзии В.С. Соловьева. Brno: Masarykova univerzita, 2013. $201 \mathrm{s.}$

Монография. Поэзия Вл. Соловьева: гностическая основа, свето-цветовая и эмоционально-звуковая образность и др.

Lorková Z. Vladimir Sorokin: tvorca mnohých tvári (innterpretačné podoby v slovenskom kultúrnom priestore). Bratislava: Stimul, 2011. $133 \mathrm{~s}$. 
Монография. Творчество В. Сорокина, рецепция в словацком культурном контексте.

Maliti $R$. Dramatička Ol’a Muchina a nová drama. Nitra: Univerzita Konštantína Filozofa, 2013. $120 \mathrm{~s}$.

Монография. Современная русская драма (со второй половины 1990-х гг.): основные течения, ключевые события и авторы. Очерк творчества О. Мухиной, стоявшей у истоков русской «новой драмы». Первый в Словакии перевод пьесы О. Мухиной «Таня-Таня».

Marčok $V$. V postmodernom labyrinte. Bratislava: Literárne a informaĉné centrum, 2010. $284 \mathrm{~s}$. Монография. Постмодернизм в критике и литературоведении (в том числе русской: Л.Г. Андреев, М. Липовецкий, В. Пелевин и др.).

Muránska N. (Kon)Texty ruskej literatúry. Nitra: Univerzita Konštantína Filozofa, Spolok slovenských spisovatel’ov, Klub F.M. Dostojevského, 2010.81 s.

Авторский сборник. Творчество М. Булгакова: проблематика, жанровое своеобразие, литературные связи и переклички (на материале романа «Мастер и Маргарита» и повести «Собачье сердце»). Проблемы поэтического перевода (в том числе русской поэзии).

Pašteková S. Moderné inšpirácie ruskej literatúry (Kultúrno-historické, poetologicko-interpretacné a recepčné súvislosti ruskej literatúry zaciatku 20. storočia). Bratislava: Veda, 2006. 152 s. Монография. Русская литература рубежа ХIX-XX вв. в культурно-историческом, поэтологическом и интерпретационном контексте. В том числе рецепция в Словакии.

Pešková $M$. Idea «nového člověka»v literatuře 20. a 30. let 20. století. Plzeň: Zapadočeská univerzita, 2012. $221 \mathrm{~s}$.

Монография. Концепция «нового человека» в советской литературе 1920-1930-е гг.

Pospišil I. Až se vyčasí... Úvahy - kritiky - glosy - eseje. Brno: Nadace Universitas Masarykiana, 2002. $132 \mathrm{~s}$.

Авторский сборник «Когда разгуляется». Размышления, эссе, заметки и сообщения. Язык и литература, преимущественно русская (писатели и поэты, их произведения, литературная критика, исследования) в современном мире.

Pospíšil I. Když se nevyčasí aneb Stmívání. Brno: Jan Sojnek, Galium, 2015. 249 s.

Авторский сборник «Когда не разгулялось, или Сумерки». Эссе, статьи, размышления о литературе, преимущественно русской.

Ryčlová I. Ruské dilema. Společenske zlo v kontextu osudu tvurčích osobnosti Ruska. Brno: Centr pro studium demokracie, 2006. $222 \mathrm{~s}$.

Авторский сборник. Эссе-размышление. Проблемы общественного зла в русской литературе XX в. - отношение различных творческих личностей и влияние на их судьбы (Л. Толстой, Е. Замятин, М. Булгаков, В. Набоков, И. Ратушинская и др.).

Ryčlová I. Mezi kladivem a kovaldinou. Brno: Centr pro studium demokracie, 2012. $200 \mathrm{~s}$. Монография. Творческие судьбы советских писателей - «Между молотом и наковальней». «Медальоны» М. Горького, В. Маяковского, М. Шолохова, В. Некрасова, А. Фадеева, В. Шаламова.

Sováková J. Románový svět Anatolije Kima. Plzeň: Západočeská univerzita, 2008. 173 s.

Монография. Проза А. Кима на материале романов «Белка», «Отец-Лес», «Остров Ионы». Философия и миропонимание, амбивалентность культурных истоков и стремление к синтезу, жанровое своеобразие, роль мифа.

Šajtar D. Černé labutě: na okraj moderní literatury ruské. Ostrava: Společnost Leopolda Vrly, 2006. $269 \mathrm{~s}$.

Авторский сборник. «Южнорусский» импульс в творчестве русских неоромантиков. На материале произведений М. Горького, А. Грина, К. Паустовского, Б. Пастернака, А. Ахматовой, Э. Багрицкого, И. Бабеля.

Ulbrechtová H. a kol. Ruská poezie 20. století. Recepční, genologické a strukturně analytické pohledy. Sborník studíi. Praha: Slovanský ústav Academie Věd České republiky, 2007. 274 s. Сборник работ чешских и словацких русистов. Русская поэзия XX в.: В. Маяковский, С. Есенин, А. Блок, П. Антокольский, Е. Евтушенко, Б. Ахмадулина, А. Вознесенский, В. Высоцкий, И. Бродский, Г. Сапгир и др. Биографические и библиографические данные об отдельных поэтах. 
Vorel J. Astrální próza Andreje Bělého: román «Petrohrad» v zrcadle esteticko-filozofických koncepcí symbolizmu. Ostrava: Ostravská univerzita, 2007. $302 \mathrm{~s}$.

Монография. Литературное наследие А. Белого - философа, поэта, прозаика и драматурга, одного из лидеров русского символизма. Анализ романа «Петербург» как образца экспериментальной прозы XX в.: духовное послание и композиция.

Winczer P. Literatúra v hl’adaní čitatel’a (20. roky: Karel Čapek, Il’ja Erenburg). Bratislava: Veda, 2013. $192 \mathrm{~s}$.

Монография. «Авторская стратегия» в отношении читателя на материале прозы 1920-х гг. (К. Чапек и И. Эренбург).

\section{ЛИТЕРАТУРА РУССКОЙ ЭМИГРАЦИИ}

Běloševská L. a kol. Vzpomínky. Deníky. Vyprávění. (Ruská emigrace v Československu). Svazek 1. Praha: Slovanský ústav Academie Věd České republiky, 2011. 672 s.

Сборник материалов. Русская эмиграция в Чехословакии. Воспоминания (К.А. Чхеидзе, Н. Мусатова). Дневники (Н.П. Кондаков, В.Ф. Булгаков). Беседы (Д.С. Гессен, И.В. Рафальская и др.).

Bubenikova M., Vachalovska L. Alfred Liudvigovich Bem (1886-1945?). Bibliography. Praha: Národní knihovna České Republiky, 1995. 109 s.

Библиографический справочник. А.Л. Бем: его произведения и работы о нем.

Drugová I. Kultúrne tradície v poézii Josefa Brodského. Bratislava: Univerzita Komenského, 2009. $132 \mathrm{~s}$.

Монография. Культурные традиции в поэзии И. Бродского: античность и барокко, М.В. Ломоносов и А.С. Пушкин, Ф.И. Тютчев, Вяч. Иванов, И. Анненский, А. Белый, А. Ахматова, О. Мандельштам, М. Цветаева, Дж. Донн, Дж. Китс, Т. Элиот и др.

Harbulová L'. a kol. Ruská a ukrajinská emigraciá na východnom Slovensku v rokoch 19191945. Prešov: Štátna vedec. knižnica, 2006. 166 s.

Сборник работ. Русская, украинская и белорусская эмиграция в восточной Словакии 1919-1945 гг: личности, биографии, общественно-культурная деятельность, вклад в культуру Словакии.

Posokhin I. Сергей Довлатов и «русский» Нью-Йорк. Bratislava: Stimul, 2013. 93 s. Монография. Творчество С. Довлатова. Русские в Нью-Йорке.

\section{РАБОТЫ, ПОСВЯЩЕННЫЕ НАСЛЕДИЮВИДНЫХ ЧЕШСКИХ И СЛОВАЦКИХ РУСИСТОВ}

Florilegium in honorem Alexandri Isačenko: ad iubilaeum centenarium oblatum. Bratislava: Coolart, 2011. $131 \mathrm{~s}$.

Юбилейный сборник памяти известного словацкого русиста А. Исаченко (1911-1970). Автобиография, материалы к биографии.

Franta V., Pospíšil I. Josef Jirásek jako rusista, slovakista a umělec slova. Brno: Tribun Evropské Unie, 2009. $160 \mathrm{~s}$.

Коллективная монография. Творческое наследие классика чешской литературы Й. Ирасека (1851-1930) - русиста, слависта и художника слова.

Pospíšil I. Srdce literatury. Alois Augustin Vrzal. Brno: Albert, 1993. 43 s.

Монография. Творческое наследие Алоиза Августина Врзала (1864-1930) - первого моравского историка русской литературы, впоследствии монаха. А. Врзал - активный пропагандист и популяризатор русской литературы, переводчик (произведения Н. Лескова, А. Чехова, В. Короленко, Л. Андреева и многих других), литературный критик. Религиозно-консервативный взгляд на русскую изящную словесность. Поиск разгадки «тайны русской души».

Slavistické reminiscence. Výbor z textů Jiř́ho Fraňka. Praha: Národní knihovna České republiky - Slovanská knihovna, 2011.

Сборник избранных работ, посвященный памяти видного пражского русиста, переводчика и издателя Й. Франька (1922-2007): «Слово о полку Игореве», творчество Н.В. Гоголя, И. Бабеля, К. Паустовского, А. Солженицына и др. 


\section{ПРОБЛЕМЫ ПЕРЕ ВОДА}

Dekanová E. Kapitoly z teórie a prekladu odborných textov. Nitra: Univerzita Konštantína Filozofa, 2009. $152 \mathrm{~s}$.

Монография. Теоретические, дидактические и практические аспекты перевода (на материале русско-словацких и словацко-русских текстов).

Maliti-Fraňová E. Tabuizovaná prekladatel'ka Zora Jesenská. Bratislava: Veda, 2007. $208 \mathrm{~s}$. Монография. Жизнь и творчество Зоры Ясенской (1909-1972), известной словацкой переводчицы английской, немецкой, французской, болгарской, но прежде всего русской (И. Эренбург, И. Бабель, Б. Пастернак, А. Солженицын и др. ) художественной литературы, чья деятельность в социалистической Чехословакии была по большей части под идеологическим запретом.

Nová koncepcia univerzitného vzdelávania prekladatel’ov a tlmočníkov na Slovensku. Nitra: Univerzita Konštantína Filozofa, 2010. 208 s.

Сборник материалов международного семинара, прошедшего в Нитре (Словакия) в марте 2010 г. Проблемы письменного и устного перевода: теория и практика, перевод как фактор объединения современной Европы и др. (в том числе на материале переводов русской литературы).

Kusá M. a. kol. Preklad a kultúra 3. Bratislava: Slovak Academic Press, 2011. $176 \mathrm{~s}$.

Коллективная монография. Перевод как часть культурной жизни общества (в том числе на материале переводов русской литературы).

Valcerová A. Hl’adanie súvislostí v básnickom preklade. Prešov: Prešovská univerzita, 2006. $220 \mathrm{~s}$. Авторский сборник. Переводы русской поэзии (М.Ю. Лермонтов, С. Есенин, А. Ахматова, М. Цветаева, А. Вознесенский и др.) на словацкий и чешский языки. Соотношение содержания и формы, вопросы ритмо- и рифмологии и др. Анализ современных переводов, а также творчества выдающегося словацкого переводчика Я. Замбора.

Vilikovský J., Hutková A. a. kol. Preklad a tlmočenie 7. Sociokultúrné aspekty prekladu a tlmočenia: prítomnost' a budúcnost'. Banská Bystrica: Univerzita Mateja Bela, 2006. $527 \mathrm{~s}$. Сборник работ словацких авторов. Социокультурный аспект письменного и устного перевода: прошлое и будущее (в том числе на материале переводов русской литературы - Н.В. Гоголя, В. Распутина и др.).

Автор-составитель:

Алла Владимировна Злочевская, доктор филол. наук

ст. науч. сотрудник

филологический факультет

МГУ имени М.В. Ломоносова
Alla V. Zlochevskaya,

Doctor of Philology

Senior Researcher

Philological Faculty

Lomonosov Moscow State University

zlocevskaya@mail.ru 